\title{
Marine Mollusca from Expedition Fiord, Western Axel Heiberg Island, Northwest Territories, Canada
}

\author{
ALEC E. AITKEN ${ }^{1}$ and ROBERT GILBERT ${ }^{2}$
}

(Received 27 September 1994; accepted in revised form 26 September 1995)

\begin{abstract}
Marine molluscs, including bivalves, gastropods and scaphopods, were recovered by dredging at depths of 3-82 $\mathrm{m}$ in Expedition Fiord, Axel Heiberg Island, Canada. Cluster analysis, based on presence/absence data at 27 stations, defined two mollusc associations within the fiord. A Portlandia-Thyasira association, characterized by the abundance of Portlandia arctica and Thyasira gouldi, inhabits silty clay substrates at depths of 32-82 m throughout the fiord. An Astarte association, characterized by the abundance of Astarte borealis and Astarte warhami, inhabits sandy mud substrates at depths of $3-32 \mathrm{~m}$ in the middle and outer fiord. The absence of this mollusc association at the fiord head suggests that the suspension-feeding molluscs that constitute this association, such as Astarte, Hiatella, Mya and Trichotropis, are intolerant of the lowered salinities and high suspendedsediment concentrations created by the discharge of Expedition River into the fiord-head environment. The Expedition Fiord molluscan fauna is compared to the molluscan fauna recorded in Jørgen Brønlund Fjord, Greenland. In the latter fiord, shallowwater $(5-19 \mathrm{~m})$ molluscan faunas are characterized by the abundance of Portlandia arctica and Hiatella arctica, while deep-water $(22-48 \mathrm{~m})$ faunas are characterized by the abundance of Thyasira dunbari. Molluscs recovered live in both of these fiords are distributed widely in high-latitude fiord and continental shelf environments.
\end{abstract}

Key words: mollusca, fiords, Canadian Arctic, Axel Heiberg Island, Greenland, ecology, zoogeography

RÉSUMÉ. On a recueilli des mollusques marins — comprenant des bivalves, des gastéropodes et des scaphopodes — par dragages effectués à des profondeurs allant de 3 à $82 \mathrm{~m}$ dans le fjord Expedition, situé dans l'île Axel Heiberg au Canada. Des analyses typologiques, établies sur les données de présence ou d'absence à 27 stations, ont permis de définir deux associations de mollusques à l'intérieur du fjord. Une association Portlandia-Thyasira, caractérisée par l'abondance de Portlandia arctica et de Thyasira gouldi, habite les substratums d'argile limoneuse à des profondeurs allant de 32 à $82 \mathrm{~m}$ dans le fjord tout entier. Une association Astarte, caractérisée par l'abondance de Astarte borealis et de Astarte warhami, habite les substratums de vase sableuse à des profondeurs allant de 3 à $32 \mathrm{~m}$ dans le milieu ou en aval du fjord. L'absence de cette association de mollusques à l'extrémité amont du fjord suggère que les mollusques se nourrissant d'éléments en suspension qui forment cette association, comme Astarte, Hiatella, Mya et Trichotropis, ne tolèrent pas les faibles salinités et les fortes concentrations de sédiments en suspension que crée le déversement de la rivière Expedition dans l'extrémité amont du fjord. On compare la faune des mollusques du fjord Expedition à celle enregistrée dans le fjord Jørgen Brønlund du Groenland. Dans ce fjord, les faunes de mollusques en eau peu profonde (de 5 à $19 \mathrm{~m}$ ) sont caractérisées par l'abondance de Portlandia arctica et de Hiatella arctica, tandis que les faunes situées en eau profonde (de 22 à $48 \mathrm{~m}$ ) sont caractérisées par l'abondance de Thyasira dunbari. Les mollusques recueillis vivants dans ces deux fjords sont largement répandus dans les fjords et les plates-formes continentales des latitudes élevées.

Mots clés: mollusques, fjords, Arctique canadien, île Axel Heiberg, Groenland, écologie, zoogéographie

Traduit pour la revue Arctic par Nésida Loyer.

\section{INTRODUCTION}

The biology of Canadian arctic fiords, specifically the fiords along the eastern coast of Baffin Island, has been the subject of several studies (Aitken et al., 1988; Dale et al., 1989; Syvitski et al., 1989; Aitken and Fournier, 1993). The biology of Canadian high arctic fiords, however, remains uninvestigated except for unpublished work by Fisheries and Oceans Canada (Hunter and Leach, 1983) and studies by Curtis (1972) and Dale (1985) on Ellesmere Island. Benthic macrofauna inhabiting Expedition Fiord, western Axel Heiberg Island, N.W.T. (Fig.1), were recovered from dredge samples taken in August 1990 as part of a collaborative research program investigating the terrestrial and marine Quaternary geology of the region(Gilbertet al., 1993; Lemmen et al., 1994). The material collected is the most complete record of the macrobenthos inhabiting a Canadian high arctic fiord: polychaetes, molluscs (gastropods, bivalves, scaphopods), crustaceans (amphipods, cumaceans, isopods, shrimp), pycnogonids, bryozoans, and echinoderms (echinoids, holothurians, ophiuroids) are represented in the collections. This paper examines the distribution of molluscs in Expedition Fiord and compares these macrofauna with the more thoroughly studied molluscan macrofaunas inhabiting

\footnotetext{
${ }^{1}$ Department of Geography, University of Saskatchewan, 9 Campus Drive, Saskatoon, Saskatchewan S7N 5A5, Canada

${ }^{2}$ Department of Geography, Queen's University, Kingston, Ontario K7L 3N6, Canada

(C) The Arctic Institute of North America
} 


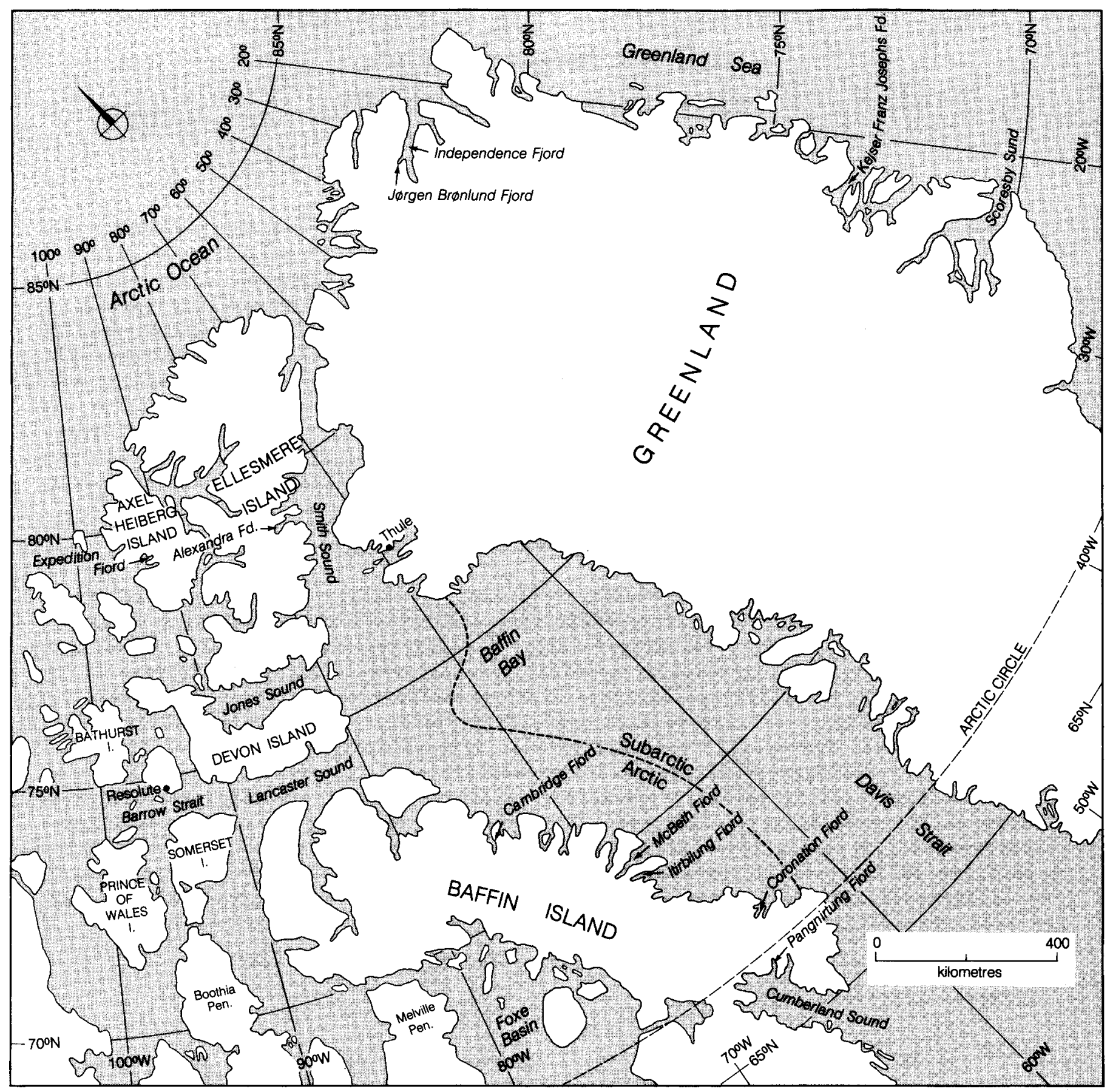

FIG. 1. Location in the Canadian Arctic Archipelago of Expedition Fiord, Axel Heiberg Island, and other places referred to in the text. The division of arctic and subarctic waters in Baffin Bay is according to Dunbar (1951).

the high-latitude fiords of eastern and northern Greenland and eastern Baffin Island.

\section{METHODS AND MATERIALS}

Working from an inflatable boat, the researchers determined the bathymetry (Fig. 2) of the fiord by surveying with an echo sounder and a subbottom profiling system (Gilbert et al., 1993). A Kolquitz dredge, fitted with a $1.0 \mathrm{~mm}$ mesh net, sampled the macrobenthos at depths of 3-82 $\mathrm{m}$. Twenty- seven dredge samples, each consisting of 5-15 L of sediment, were recovered from several sites within the fiord (Fig. 2). Each dredge sample was sieved on site through a $0.5 \mathrm{~mm}$ brass sieve in seawater. Material retained on the sieve was preserved in buffered formalin. In the laboratory, marine invertebrates were sorted manually under a binocular microscope at $10 \times$ to $25 \times$ magnification and identified to the level of species whenever possible. The binomial nomenclature used for mollusc species in this study conforms with Macpherson (1971) and Lubinsky (1980). Subsamples of sediment recovered in the dredge, each 40 to $60 \mathrm{~g}$, were 

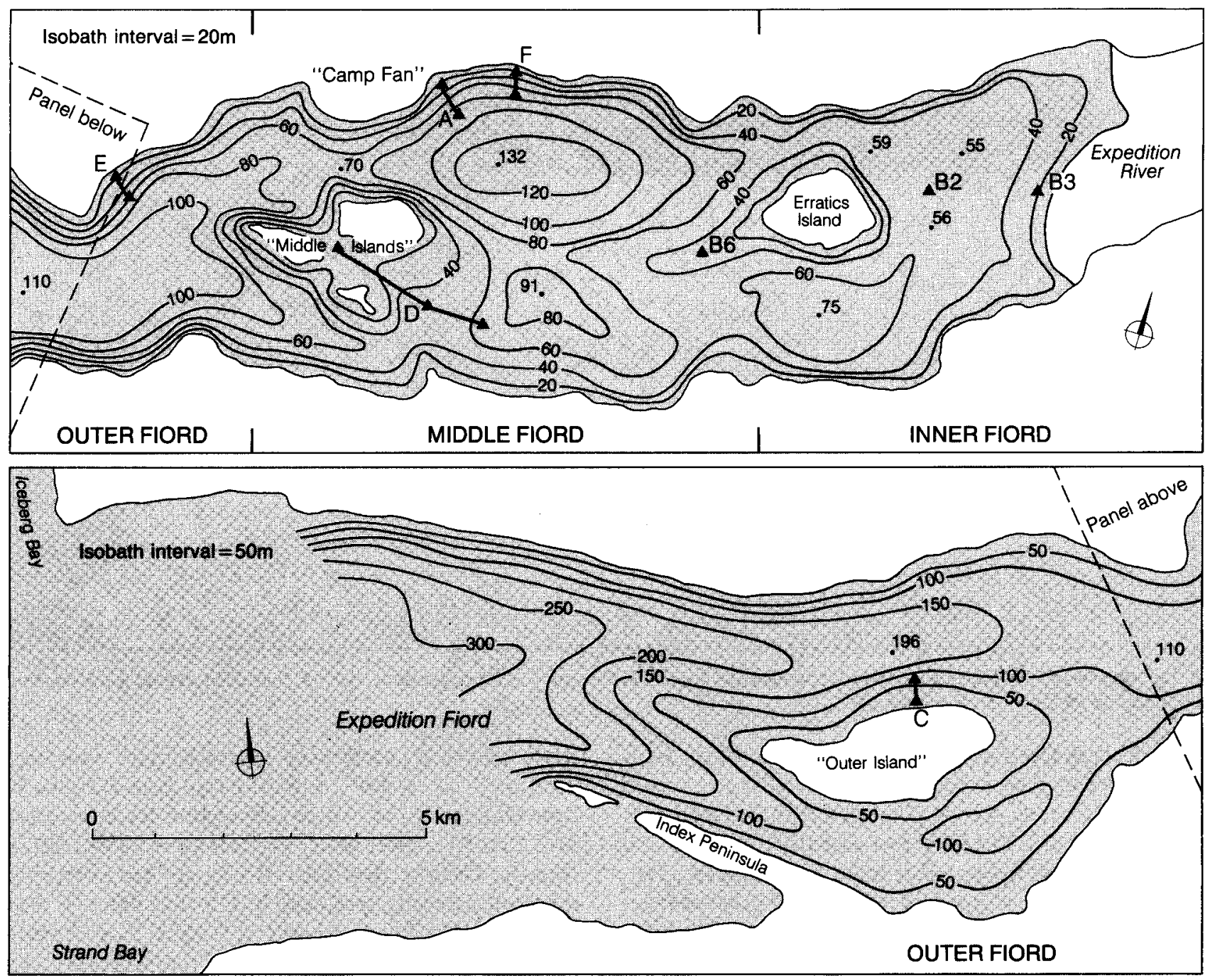

FIG. 2A. (upper frame) The bathymetry of the inner and middle basins of Expedition Fiord showing the location of dredge sampling stations (after Gilbert et al., 1993). At sites A, D and F, dredge samples were taken at intervals along a transect line perpendicular to the shore. Dredge samples were taken at various locations within the inner basin; only those stations that yielded molluscs (B2, B3 and B6) are shown. Sample depths are given in Appendix 1. Informal place names are in quotation marks. FIG. 2B. (lower frame) The bathymetry of the outer basin of Expedition Fiord showing the location of dredge sampling stations (after Gilbert et al., 1993). At sites $\mathrm{C}$ and $\mathrm{E}$, dredge samples were taken at intervals along a transect line perpendicular to the shore; sample depths are given in Appendix 2 . Informal place names are in quotation marks.

retained for the determination of grain-size distribution by sieving and SediGraph analysis.

Seawater temperature, salinity, and suspended sediment content were measured irregularly throughout the fiord during the open-water period of 1988 and 1990 (Gilbert, 1990; Gilbert et al., 1993). A compilation of the hydrographic data acquired in Expedition Fiord is available from the authors upon request.

At present, there is a dearth of information relating to the benthic marine ecology of the Canadian Arctic Archipelago. For comparison, we examined the distribution of molluscs recovered by dredging in Expedition Fiord and Jørgen Brønlund Fjord, northeastern Greenland (Fig. 3; Schiøtte, unpubl. data). The presence and abundance of molluses in each dredge sample were recorded and entered in a data matrix; only those stations that yielded molluscs were included in the data matrix. Separate matrices were developed for Expedition Fiord and Jørgen Brønlund Fjord (Appendices $1-3)$. These data matrices were reduced to include only those species present at two or more stations, then evaluated by cluster analysis using SAS/STAT Version 6 clustering procedures (SAS Institute Inc., 1989). The sampling methods employed in Expedition Fiord and Jørgen Brønlund Fjord preclude quantitative analysis of the benthic macrofauna. In this situation Jaccard's coefficient, which is based on the presence or absence of species within a sample, was employed to create similarity matrices. Clusters present within the similarity matrices were determined by Ward's method, as recommended by Jones (1988).

\section{PHYSICAL ENVIRONMENT}

\section{Study Area}

As discussed in detail by Gilbert et al. (1993) and Lemmen et al.(1994), Expedition Fiord leads from glaciated highlands 


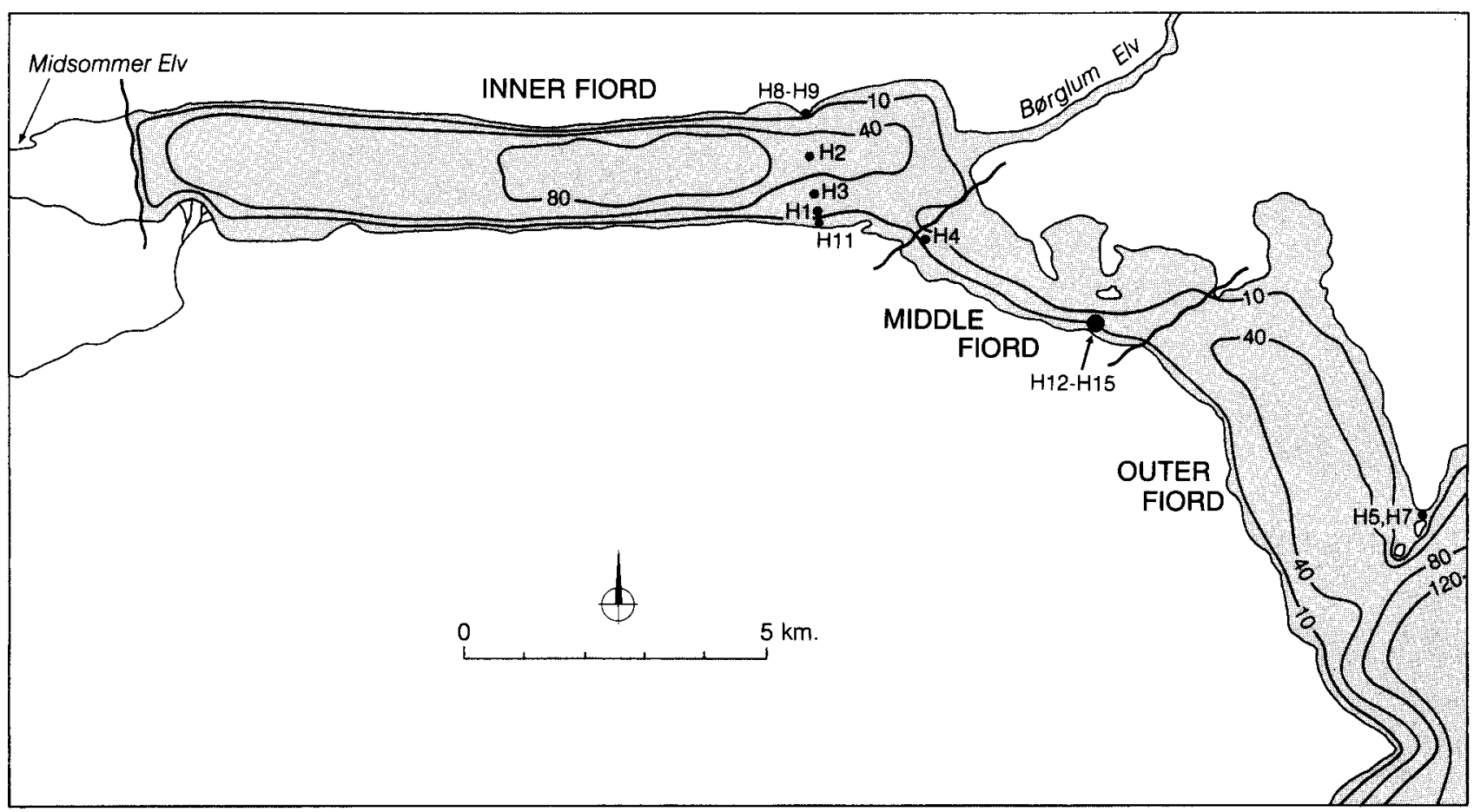

FIG. 3. The bathymetry of Jørgen Brønlund Fjord showing the location of dredge sampling stations (after Just, 1970). Only those stations that yielded molluscs are shown. Sample depths are given in Appendix 3.

in central Axel Heiberg Island into Strand Bay on the western coast of the island. Expedition Fiord is normally ice-covered 11 to 12 months of the year; sea ice more than $2 \mathrm{~m}$ thick was observed in the fiord. The fiord was virtually free of sea ice, however, throughout the period of study, 1-14 August 1990. In addition to sea ice, icebergs of various sizes, calved from a tidewater glacier in adjacent Iceberg Bay (Fig. 2B), were observed in the fiord. The fiord's major source of water and sediment is Expedition River, which drains an area covered extensively by glaciers. The rapid advance of the Expedition River delta, averaging $9 \mathrm{~m} \mathrm{a}^{-1}$ since 1959 , reflects the input of large quantities of sediment at the fiord head (Gilbert, 1990; Gilbert et al., 1993).

A sill (at $70 \mathrm{~m}$ depth north of the "Middle Islands" and less than $60 \mathrm{~m}$ depth south of the "Middle Islands") separates several shallow basins (maximum depth $132 \mathrm{~m}$ ) from the outer fiord (to the west of the "Middle Islands" and north of "Outer Island"), which deepens to more than $300 \mathrm{~m}$ near the mouth (Fig. 2B). This sill prevents icebergs with deep keels from entering the eastern portion of the fiord, although icebergs with shallow keels move freely throughout the fiord during periods of open water (Gilbert et al., 1993). Bottom sediments above $70 \mathrm{~m}$ depth east of the sill are scoured extensively by iceberg keels to produce a distinctly rough bottom topography. The fiord floor west of the "Middle Islands" is also scoured extensively by iceberg keels, suggesting that there is no sill between outer Expedition Fiord and Iceberg Bay at any depth shallower than $300 \mathrm{~m}$ (Gilbert et al., 1993).

Measurements of temperature and salinity in Expedition Fiord recorded in 1988 and 1990 indicate the presence of a well-defined overflowing cap. A sharp pycnocline at $6-6.5 \mathrm{~m}$ depth separates overflowing brackish water with temperatures from $1.8^{\circ}$ to $6.9^{\circ} \mathrm{C}$ and salinities from $1.2 \%$ o to $12.1 \%$ o from seawater below, where temperature decreases gradually to $-2^{\circ} \mathrm{C}$ at $50 \mathrm{~m}$ and salinity varies between $25 \%$ and $33.7 \%$ o (Fig. 4). The overflow formed a strong cap everywhere in the fiord, thinning gradually to $4.5-5 \mathrm{~m}$ depth at the fiord mouth. Staff gauge readings at "Camp Fan" from 1-14 August 1990 showed a semidiurnal tide with a mean range of $0.42 \mathrm{~m}$; thus, tidal currents are probably ineffective as an agent of mixing across the pycnocline.

The upper $50 \mathrm{~m}$ of the water column is well-oxygenated throughout the fiord. Dissolved oxygen values range from 9.3 to $13.9 \mathrm{~mL} \mathrm{~L}^{-1}$, with the greatest values occurring at depth. Gilbert (1990) reported values of 9.4 to $11.8 \mathrm{~mL} \mathrm{~L}^{-1}$ at the fiord head in August, 1988.

\section{Water Masses}

The distribution of benthic molluses at high latitudes is influenced strongly by the distribution of water masses. Along the coasts of the Canadian Arctic Archipelago and northern Greenland, the continental shelf extends to depths of 400-650 m (Johnson et al., 1990). Three distinct water masses occur at these depths in the Arctic Ocean basin; fiord water, polar water, and Atlantic water. Data relating to the physical properties of polar and Atlantic waters in the Arctic Ocean basin are presented by Coachman and Aagaard (1974) and Lewis (1989). A brief summary of these data follows.

Polar waters occupy the uppermost $200 \mathrm{~m}$ of the Arctic Ocean basin and exhibit varying physical characteristics that reflect the inflow and mixing of Pacific and Atlantic waters with fresh water derived from the land and the decay of sea 


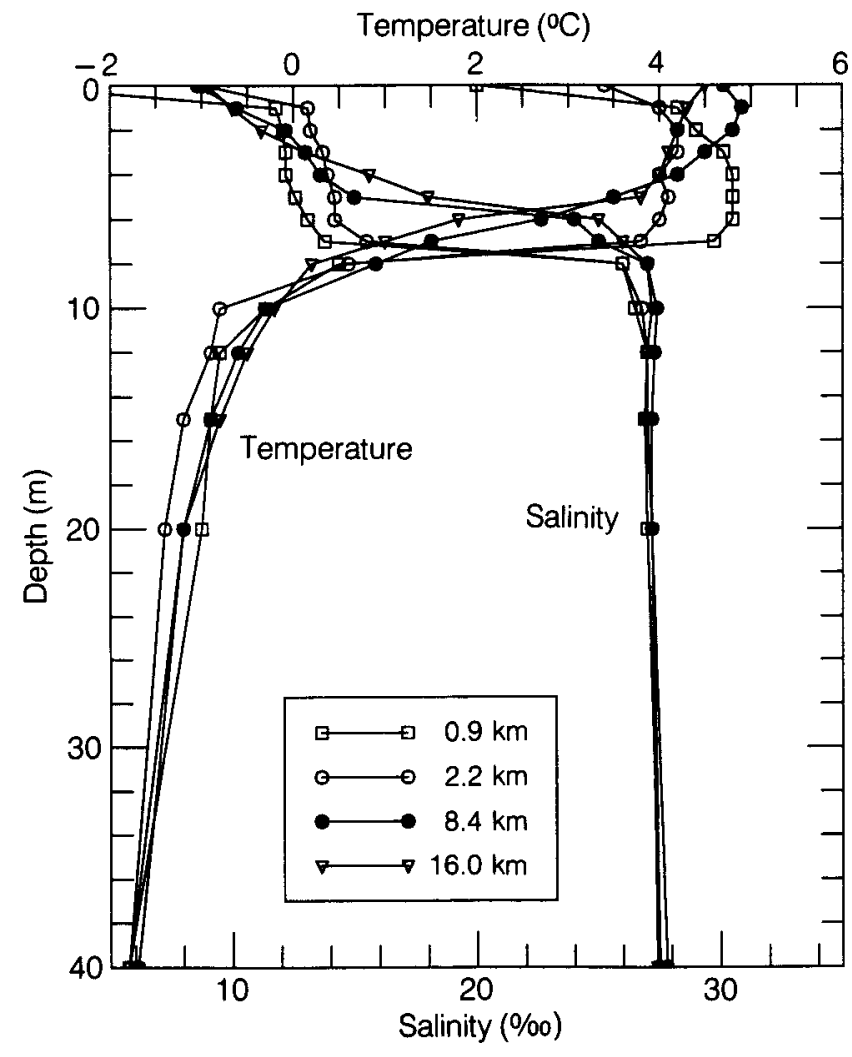

FIG. 4. Temperature and salinity in the upper water of Expedition Fiord on 18 August 1988 at stations from 0.9 to $16 \mathrm{~km}$ from the mouth of Expedition River at the fiord head (after Gilbert, 1990).

ice. Along the northern coast of the Canadian Arctic Archipelago and Greenland, polar waters exhibit summer temperatures of $1-2^{\circ} \mathrm{C}$ and salinities of $30 \%$ to $32 \%$ at $50 \mathrm{~m}$ depth, increasing to $34.5 \%$ at $200 \mathrm{~m}$. In winter, polar waters exhibit salinities of $32 \%$ o to $34 \%$ and temperatures approaching the freezing point of seawater.

The Atlantic layer lies beneath polar waters at depths of $200-500 \mathrm{~m}$. The source of this water is the north Atlantic Ocean via the Norwegian and Greenland Seas. Over the Canadian continental shelf, Atlantic waters exhibit temperatures lower than $0.5^{\circ} \mathrm{C}$ and salinties of $34.92 \%$ o to $34.99 \%$.

Danish authors (see review by Ockelmann, 1958), working in the fiords of eastern Greenland, differentiate between polar waters and fiord waters, the latter representing relatively warm $\left(>0^{\circ} \mathrm{C}\right)$, low-salinity $(<20 \%$ o $)$ water produced by the inflow of fresh water from rivers discharging into fiords and by the melting of sea ice (Ockelmann, 1958). We employ the term "fiord water" to represent the overflowing brackish-water layer described earlier in this paper.

The outflow of water from the Arctic Ocean basin into Baffin Bay, through the channels of the Canadian Arctic Archipelago, contributes to the Baffin Current. This ocean current is formed by cold, low-salinity water $\left(-1.8\right.$ to $1.8^{\circ} \mathrm{C}$, $<34.5 \%$; Dunbar, 1951; Meunch, 1971) that flows southward at depths of 100-300 m across the continental shelf of eastern Baffin Island. This water mass is of Atlantic origin and enters Baffin Bay via Davis Strait, where it is modified by cooling and mixing with surface runoff in northeastern Baffin Bay; or it is modified by cooling and freshening within the Arctic Ocean prior to entering Baffin Bay via Smith, Jones, and Lancaster Sounds (Meunch, 1971).

The Greenland Current flows below the Baffin Current. It is a relatively warm, saline water mass $\left(0^{\circ}\right.$ to $2.0^{\circ} \mathrm{C}, 34.2 \%$ o to $35 \%$; Bailey, 1957; Meunch, 1971) that flows southward at depths of 300-1300 $\mathrm{m}$ across the outer continental shelf and slope of eastern Baffin Island. This water originates in the Atlantic Ocean and is advected north via Davis Strait into Baffin Bay by the West Greenland Current. Here the Greenland Current water mixes with Baffin Current water and loses heat as it flows southward along the Baffin Island coast.

Mixing of Baffin Current water and Greenland Current water occurs across a broad front extending from $67^{\circ} \mathrm{N}$ on eastern Baffin Island to $77^{\circ} \mathrm{N}$ on western Greenland (Fig. 1). This region, occupied by waters of mixed polar and Atlantic origin, is known as the subarctic marine zone (Dunbar, 1951).

\section{RESULTS}

The 26 species of marine molluscs recovered from Expedition Fiord, Axel Heiberg Island (17 bivalves, 8 gastropods and 1 scaphopod) cluster into two discrete mollusc associations (Table 1 and Fig. 5). A Portlandia-Thyasira association occurs on sandy mud substrates (Table 2) in the prodeltaic environment of Expedition River and on silty clay substrates (Table 2) at depths of 32-82 $\mathrm{m}$ elsewhere in the fiord. Portlandia arctica and Thyasira gouldi are common species in this mollusc association. Species diversity increases seawards from the prodeltaic environment (i.e., stations B2 and B3, Fig. 2A) through the addition of the bivalves Yoldiella spp. and Delectopecten greenlandicus and the scaphopod Siphonodentalium lobatum in the middle and outer fiord.

An Astarte association occurs throughout Expedition Fiord on silty clay substrates (Table 2) at depths of 3-32 m, except at the fiord head (i.e., stations B2 and B3; Fig. 2A). The bivalves Astarte borealis and Astarte warhami and the gastropod Trichotropis borealis are the most common and abundant species in this mollusc association. The bivalves Macoma calcarea, Macoma loveni and Hiatella arctica and the gastropod Cylichna occulta occur commonly and in low abundance at Sites A, D and F in the middle fiord (Fig. 2A). The diversity of this molluscan association increases in the outer fiord (i.e., Sites $\mathrm{C}$ and E; Fig. 2A,B), through the addition of the bivalves Clinocardium ciliatum and Cuspidaria arctica and the gastropod Oenopota novajasemliensis.

The molluscan fauna recorded at sampling stations C4, D4 and D5 marks a transition from the shallow-water Astarte association to the deep-water Portlandia-Thyasira association. This macrofauna consists of Astarte borealis and Astarte warhami, representing elements of the Astarte association, and Yoldiella spp. and Siphonodentalium lobatum, representing elements of the Portlandia-Thyasira association .

Two mollusc associations were identified by cluster analysis in Jørgen Brønlund Fjord (Table 1 and Fig. 6). A Thyasira 


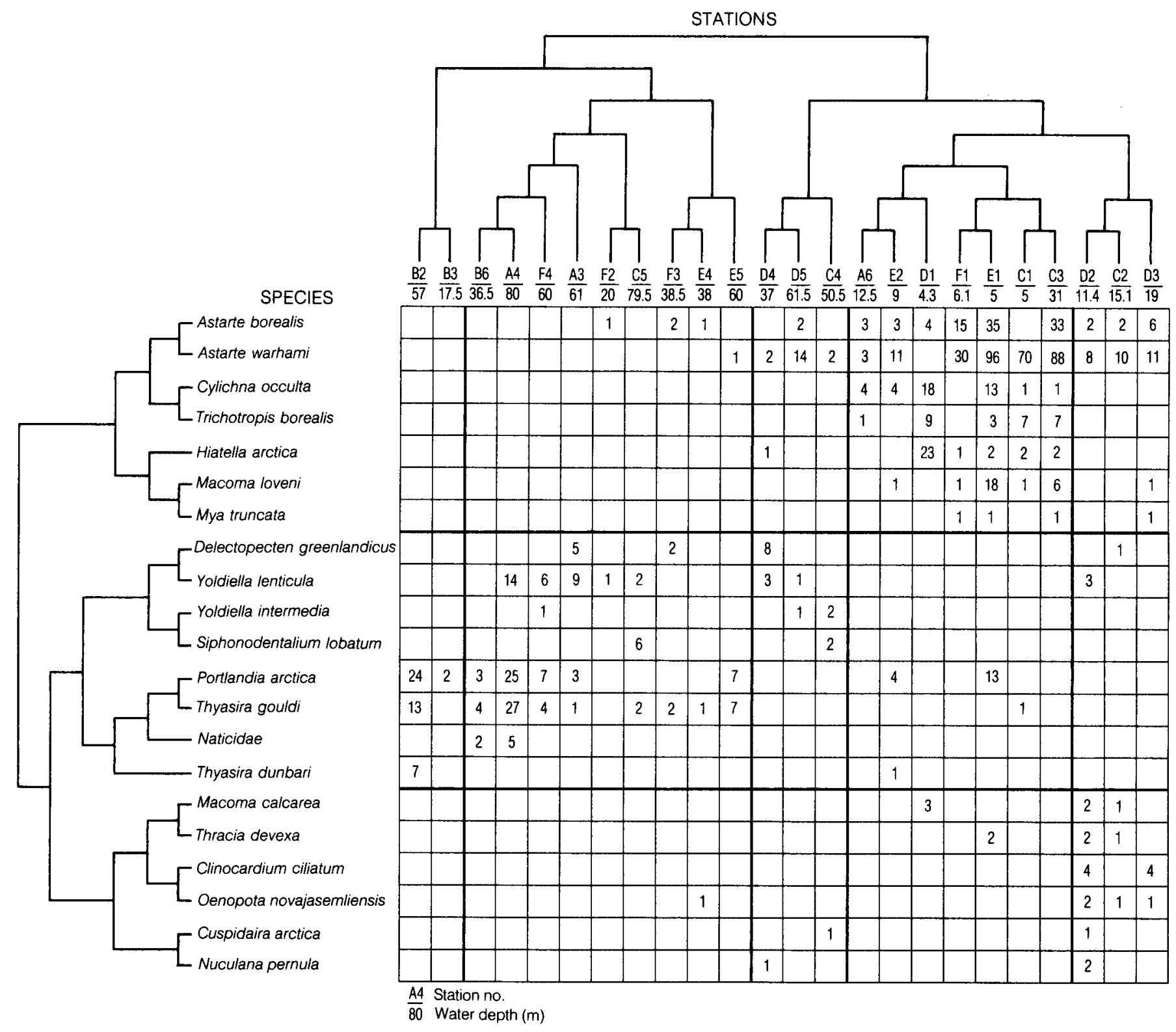

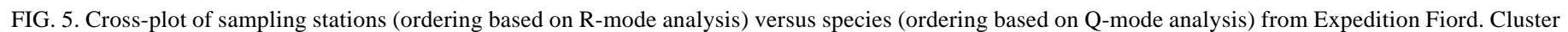

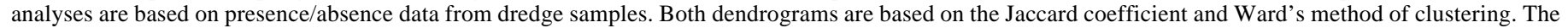

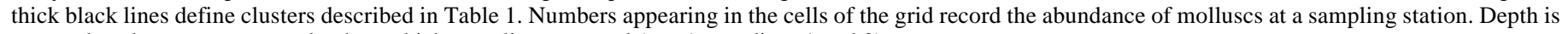
reported as the average water depth at which sampling occurred (see Appendices 1 and 2).

TABLE 1. Mollusc associations determined by cluster analysis of the presence or absence of species in dredge samples recovered from Expedition Fiord and Jørgen Brønlund Fjord.

\begin{tabular}{|c|c|c|}
\hline & Association & Stations \\
\hline \multirow[t]{3}{*}{ Expedition Fiord: } & $\begin{array}{l}\text { Portlandia-Thyasira } \\
\text { (prodelta) }\end{array}$ & B2, B3 \\
\hline & $\begin{array}{l}\text { Portlandia-Thyasira } \\
\text { (middle \& outer Fiord) }\end{array}$ & $\begin{array}{l}\text { A3, A4, B6, C5, E4, E5, } \\
\text { F3, F4 }\end{array}$ \\
\hline & Astarte & $\begin{array}{l}\text { A6, C1, C2, C3, D1, D2, } \\
\text { D3, E1, E2, F1 }\end{array}$ \\
\hline \multirow[t]{2}{*}{ Jørgen Brønlund Fjord: } & Portlandia-Hiatella & $\begin{array}{l}\mathrm{H} 1, \mathrm{H} 4, \mathrm{H} 7, \mathrm{H} 9, \mathrm{H} 11, \\
\mathrm{H} 12, \mathrm{H} 13, \mathrm{H} 14, \mathrm{H} 15\end{array}$ \\
\hline & Thyasira & $\mathrm{H} 2, \mathrm{H} 3, \mathrm{H} 5, \mathrm{H} 8$ \\
\hline
\end{tabular}

association, consisting of Thyasira dunbari, Thyasira pygmaea and Yoldiella intermedia occurs on substrates consisting of clay and stones at depths of 22 to $48 \mathrm{~m}$ in the inner and outer basins of the fiord. Bottom water temperatures and salinities, recorded in May and June 1966 , range from $-1.33^{\circ} \mathrm{C}$ to $-0.70^{\circ} \mathrm{C}$ and from $31.2 \%$ o to $31.6 \%$, respectively (Just, 1970).

A Portlandia-Hiatella association occurs on heterogeneous substrates consisting of gravel, sand and clay at depths of 5-19 m throughout Jørgen Brønlund Fjord. Bottom water temperatures and salinities, recorded in May and June 1966, range from $-0.23^{\circ} \mathrm{C}$ to $-0.93^{\circ} \mathrm{C}$ and from $30.0 \%$ o to $33.1 \%$, respectively (Just, 1970). This mollusc association is characterized by the presence and abundance of the bivalves Portlandia arctica and Hiatella arctica. The diversity of this 


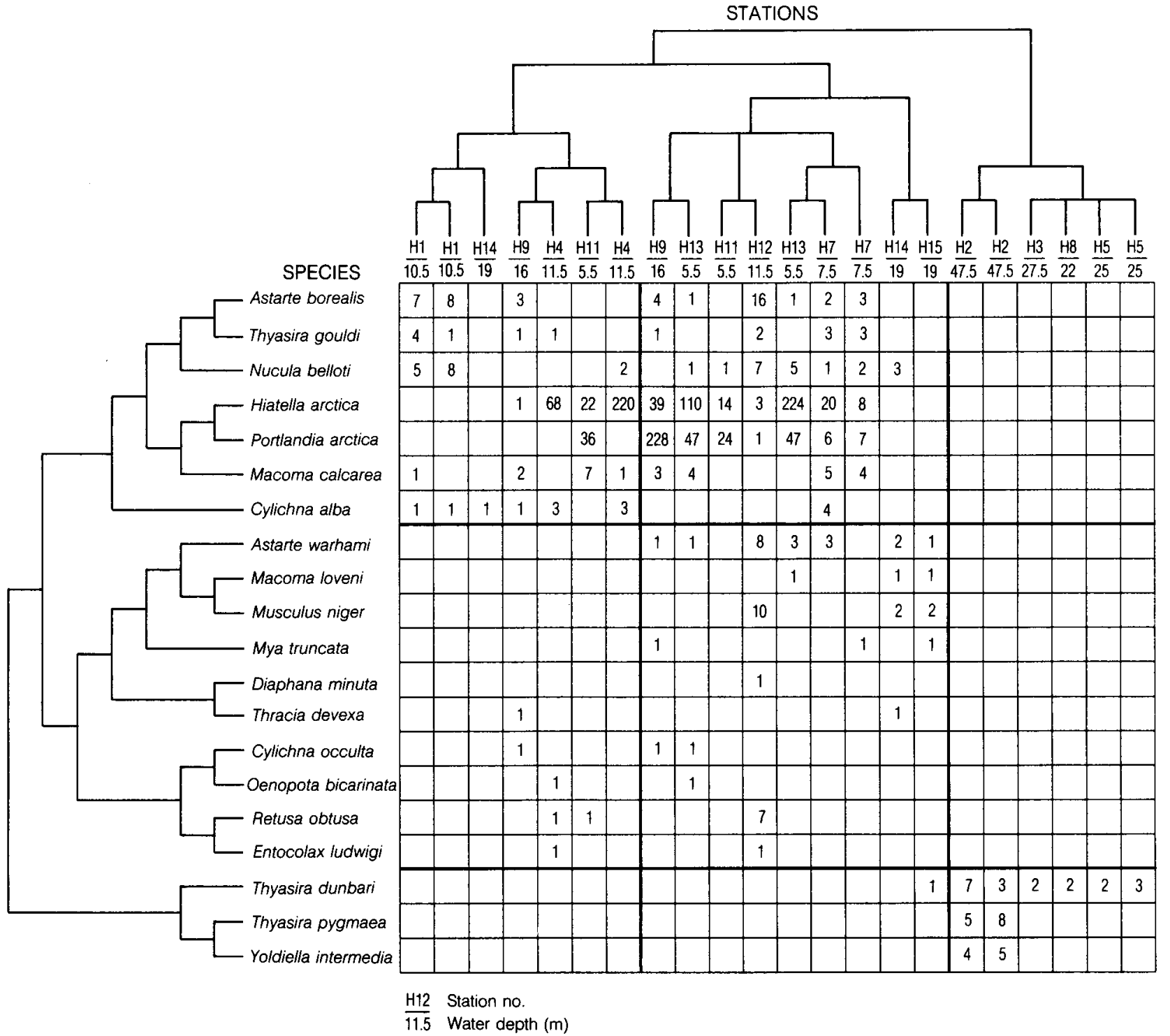

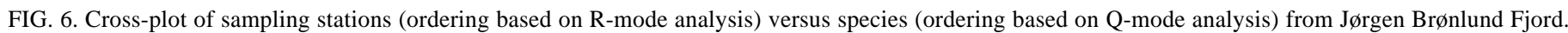

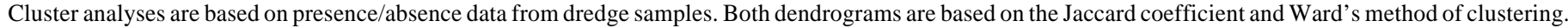

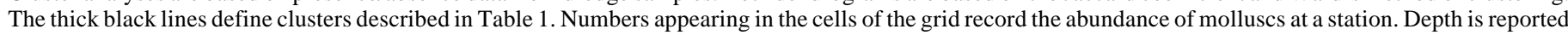
as the average water depth at which sampling occurred (see Appendix 3).

TABLE 2. Texture of bottom sediments recovered from Expedition Fiord.

\begin{tabular}{|c|c|c|c|}
\hline & $\%$ Gravel \& Sand & $\%$ Silt & $\%$ Clay \\
\hline \multicolumn{4}{|l|}{ Astarte Association: } \\
\hline \multicolumn{4}{|c|}{ Middle and outer fiord (10 samples; $3-32 \mathrm{~m}$ depth) } \\
\hline Mean & 1.1 & 32.4 & 66.5 \\
\hline Standard Deviation & 1.4 & 8.2 & 8.3 \\
\hline \multicolumn{4}{|c|}{ Portlandia-Thyasira Association: } \\
\hline \multicolumn{4}{|c|}{ Fiord head (3 samples; $15-57 \mathrm{~m}$ depth) } \\
\hline Mean & 9.3 & 43.7 & 47.2 \\
\hline Standard Deviation & 6.1 & 15.3 & 19.9 \\
\hline \multicolumn{4}{|c|}{ Middle and outer fiord (12 samples; $32-81 \mathrm{~m}$ depth) } \\
\hline Mean & 1.1 & 37.9 & 61.9 \\
\hline Standard Deviation & 0.9 & 9.2 & 9.3 \\
\hline
\end{tabular}

mollusc association increases seawards from the fiord head. The bivalves Astarte borealis, Macoma calcarea, Nucula belloti and Thyasira gouldi, and the gastropod Cylichna alba occur commonly and in low abundance in the inner and middle fiord. In addition to these species, the bivalves Astarte warhami and Musculus niger occur commonly and in low abundance in the outer fiord.

\section{DISCUSSION}

\section{Zoogeography}

Lemche (1941), Thorson (1944), Ockelmann (1958), Macpherson (1971), and Lubinsky (1980) all have noted the similarity in species composition of mollusc faunas 
TABLE 3. Depth distribution in metres $(\mathrm{m})$ of molluscs recovered from high arctic fiord and continental shelf environments.

\begin{tabular}{|c|c|c|c|c|c|c|}
\hline & \multicolumn{2}{|c|}{ Axel Heiberg Island } & \multirow{2}{*}{$\begin{array}{c}\text { Ellesmere Island } \\
\text { C }\end{array}$} & \multicolumn{2}{|c|}{ Greenland } & \multirow{2}{*}{$\begin{array}{c}\text { Svalbard } \\
\text { F }\end{array}$} \\
\hline & A & $\mathrm{B}$ & & $\mathrm{D}$ & $\mathrm{E}$ & \\
\hline \multicolumn{7}{|l|}{ Bivalvia } \\
\hline Astarte borealis & $3-45$ & & & $12-52$ & $6-16$ & $15-25$ \\
\hline Astarte warhami & $3-53$ & & & & $6-47$ & \\
\hline Clinocardium ciliatum & $9-20$ & & & $12-52$ & & $15-18$ \\
\hline Cuspidaria arctica & $9-14$ & & & & $30-80$ & \\
\hline Delectopecten greenlandicus & $14-67$ & 152,180 & & & $10-190$ & \\
\hline Hiatella arctica & $3-40$ & & Intertidal & $8-64$ & $2-45$ & $1-25$ \\
\hline Macoma calcarea & $4-16$ & & Intertidal & $8-64$ & $2-16$ & \\
\hline Macoma loveni & $3-32$ & & & & $6-38$ & \\
\hline Mya truncata & $3-32$ & & Intertidal & $8-64$ & $2-40$ & $12-15$ \\
\hline Portlandia arctica & $4-81$ & & & & $3-18$ & \\
\hline Nuculana pernula & $9-40$ & & & $40-54$ & $30-80$ & \\
\hline Thracia devexa & $4-16$ & & & & $16-140$ & \\
\hline Thyasira gouldi & $5-82$ & & & & $8-16$ & \\
\hline Thyasira dunbari & $8-10,57$ & & & & $19-47$ & \\
\hline Yoldiella fraterna & $32-45$ & 152 & & & & \\
\hline Yoldiella intermedia & $34-66$ & $160,425-604$ & & & $45-190$ & \\
\hline Yoldiella lenticula & $9-82$ & $180-604$ & & & $30-50$ & \\
\hline \multicolumn{7}{|l|}{ Scaphopoda } \\
\hline Siphonodentalium lobatum & $48-72$ & 175,487 & & & $50-80$ & \\
\hline \multicolumn{7}{|l|}{ Gastropoda } \\
\hline Cylichna alba & $18-20$ & & Intertidal & & $5-190$ & $15-18$ \\
\hline Cylichna occulta & $4-32$ & & & & $3-80$ & $15-18$ \\
\hline Lepeta caeca & $34-40$ & & & 54 & $15-35$ & $1-10$ \\
\hline Oenopota cinerea & $4-6$ & & & & & \\
\hline Oenopota decussata & $30-32$ & & & & & \\
\hline Oenopota novajasemliensis & $9-65$ & & & & $6-40$ & \\
\hline Oenopota reticulata & $8-10$ & & & & $3-50$ & \\
\hline Trichotropis borealis & $4-32$ & & & $18-45$ & $2,68,140$ & \\
\hline
\end{tabular}

Sources of information: A - Expedition Fiord, Axel Heiberg Island, this study; B - Axel Heiberg Island continental shelf (Wagner, 1964) and unpublished (see Appendix 4); C - Cape Herschel and Alexandra Fiord, Ellesmere Island (Dale, 1985); D - continental shelf off Thule, Northwest Greenland (Vibe, 1939, 1950); E - Jørgen Brønlund Fjord, Greenland (Schiøtte, 1989); F - Van Keulen Fjord, Spitsbergen, Svalbard (Rózycki, 1984).

inhabiting high-latitude continental shelves in the Northern Hemisphere. Table 3 illustrates clearly that the marine molluscs inhabiting Expedition Fiord and Jørgen Brønlund Fjord are distributed widely in high arctic estuarine and continental shelf environments.

The arctic marine zone is defined by the distribution of polar waters on the continental shelves of the Canadian Arctic Archipelago (Fig. 1). Amongst the molluscs recorded from Expedition Fiord, the following species are associated with the arctic marine zone: Astarte warhami, Cuspidaria arctica, Delectopecten greenlandicus, Oenopota novajasemliensis, Portlandia arctica, Thracia devexa, Thyasira dunbari and Yoldiella intermedia. Lubinsky (1980:38) notes that Thyasira dunbari is a shallow water, high arctic species endemic to the northernmost islands of the Canadian Arctic Archipelago and northern Greenland. The remaining 18 species possess a broad tolerance to higher temperatures and salinities and inhabit the marine subarctic zone as well. This group of panarctic molluscs includes: Astarte borealis, Clinocardium ciliatum, Cylichna alba, Cylichna occulta, Hiatella arctica, Lepeta caeca, Macoma calcarea, Macoma loveni, Mya truncata, Nuculana pernula, Oenopota cinerea, Oenopota decussata, Oenopota reticulata, Siphonodentalium lobatum, Thyasira gouldi, Trichotropis borealis, Yoldiella fraterna and Yoldiella lenticula. Note that Siphonodentalium lobatum, Yoldiella fraterna and Yoldiella lenticula inhabit water depths associated with the Atlantic layer in the Arctic Ocean basin (Table 3).

Ice Action in the Sublittoral Environment of Expedition Fiord

The absence of invertebrate macrofauna at depths less than $3 \mathrm{~m}$ throughout Expedition Fiord can probably be attributed to the presence of a thick, landfast sea ice cover within Expedition Fiord. Numerous authors have observed a barren zone to depths as great as $5 \mathrm{~m}$ that apparently develops in association with landfast sea ice (Madsen, 1936, 1940; Ellis and Wilce, 1961; Bergeron and Bourget, 1984; Thomson et al., 1986). Mortality due to direct freezing of organisms during icefoot development, abrasion by drift ice during breakup in early summer, and physiological stress associated with lower salinities created by melting sea ice and icebergs in summer are believed to contribute to the absence of a shallow-water macrofauna in high arctic fiords. High mortality of shallow marine invertebrates has been observed on shorelines affected by ice abrasion (MacGinitie, 1955; George, 1977; Petersen, 1977; Gordon and Desplanque, 1983; Aitken et al., 1988). Active abrasion of shorelines by first-year and 
multiyear ice floes was observed in Expedition Fiord during the summer of 1991.

At all sampling sites within Expedition Fiord, with the exception of stations B2 and B3 (Fig. 2A), iceberg scouring has also disturbed the seafloor (Gilbert et al., 1993). The effects of iceberg scouring on the physical properties of marine sediments have received considerable attention in the literature (Reimnitz et al., 1978; Pereira et al., 1988; Bass and Lever, 1989; Woodworth-Lynas et al., 1989); however, less is known about the effects of iceberg scouring on sublittoral benthic community structure. Petersen (1977) has observed that shorelines in southern Greenland exposed to scouring by drifting ice floes and icebergs are devoid of macrofauna to depths of 5 to $10 \mathrm{~m}$. On the inner continental shelf of the Beaufort Sea, the low abundance and biomass of macrofaunal organisms observed at depths of 15 to $25 \mathrm{~m}$ is attributed in part to direct destruction of organisms by ice scouring (Carey and Ruff, 1977; Carey, 1991).

Both epifaunal and infaunal organisms may also be frozen directly into developing landfast sea ice and then removed subsequently from their original habitat by drifting ice floes during ice breakup (Medcof and Thomas, 1974; Aitken et al., 1988; Reimnitz et al., 1992). Reimnitz et al. (1992) observed carcasses of shallow marine invertebrates, including the bivalves Astarte borealis, Hiatella arctica and Mya truncata, on the surface of drifting ice floes in channels of the Canadian Arctic Archipelago. These organisms are believed to have been frozen into the ice through the combined action of anchor ice growth and suspension freezing during frazil formation. Both of these processes operate at water depths as great as 20-30 m (Reimnitz and Kempema, 1987; Reimnitz et al., 1987). Although the organisms observed by Reimnitz et al. (1992) are common in the Astarte association inhabiting Expedition Fiord, no marine invertebrates were observed incorporated into sea ice.

\section{Comparison with Other High-Latitude Fiords}

The Portlandia-Thyasira association inhabiting the prodeltaic environment of Expedition Fiord is characterized by the low diversity and abundance of molluscs. This molluscan association shares these characteristics with Portlandia associations recorded from prodeltaic environments in Coronation and Itirbilung Fiords (Syvitski et al., 1989; Aitken and Fournier, 1993) and Scott Inlet (Thomson et al., 1986) along the eastern coast of Baffin Island. Species represented in the Portlandia-Thyasira association include Portlandia arctica, Thyasira gouldi and Thyasira dunbari (Table 4).

Water samples recovered from $20 \mathrm{~m}$ depth in inner Expedition Fiord indicate that suspended sediment concentrations vary from 6 to $10 \mathrm{mgL}^{-1}$, temperatures are less than $-1.0^{\circ} \mathrm{C}$, and salinity is greater than $25 \%$ o (cf. data at $0.9 \mathrm{~km}$, Fig. 4). The three-orders-of-magnitude decrease in suspended sediment concentration between the mouth of Expedition River (i.e., 2-6 gL-1 ; Maag, 1969; Gilbert, 1990) and the prodeltaic environment indicates high rates of sedimentation (Gilbert et al., 1993).
As was the case in Expedition Fiord, there is a significant input of fresh water and suspended sediment to the fiord-head environment of Coronation and Itirbilung Fiords (Syvitski et al., 1989, 1990; Syvitski and Hein, 1991). In both of these fiords, suspended sediment concentrations in surface waters decrease rapidly seaward from the fiord head. For example, suspended sediment concentrations decrease from 88-153 $\mathrm{mgL}^{-1}$ at the mouth of the Itirbilung River to $1-4 \mathrm{mgL}^{-1}$ within the prodeltaic environment of Itirbilung Fiord, indicating high rates of sedimentation (Syvitski and Hein, 1991). Water samples recovered at $20 \mathrm{~m}$ depth in the prodeltaic environment of Coronation and Itirbilung Fiords indicate that temperature varies from $0^{\circ} \mathrm{C}$ to $-1^{\circ} \mathrm{C}$ and salinity varies from $30 \% o$ to $32.5 \%$ o (Asprey et al., 1983; Trites et al., 1983; Dale et al., 1989). It is apparent that the organisms constituting the Portlandia-Thyasira association in prodeltaic environments tolerate high suspended-sediment concentrations, rapid sedimentation rates, cold temperatures and variable salinity.

In contrast to the prodeltaic environment, the habitat of the Portlandia-Thyasira association observed in the middle and outer basins of Expedition Fiord is characterized by low sedimentation rates (about $0.5 \mathrm{~mm} \mathrm{a}^{-1}$; Gilbert et al., 1993) and salinities greater than $30 \%$. The presence of Delectopecten greenlandicus, Yoldiella spp. and Siphonodentalium lobatum differentiates this mollusc association from the PortlandiaThyasira association inhabiting the prodeltaic environment. Mollusc faunas inhabiting depths greater than $30 \mathrm{~m}$ in Baffin Island fiords and greater than $45 \mathrm{~m}$ in Greenland fiords are characterized by species also found in the Portlandia-Thyasira association of Expedition Fiord.Delectopecten greenlandicus, Thyasira gouldi and Yoldiella spp. are common in the Astarte crenata-Bathyarca glacialis association that occurs on muddy substrates at depths of 45 to $200 \mathrm{~m}$ in Greenland fiords (Spärck, 1933; Thorson, 1934). In Baffin Island fiords Delectopecten greenlandicus has been observed on muddy substrates at depths of $30-150 \mathrm{~m}$, although it is most abundant on coarse substrates associated with fiord-mouth sills (Dale et al., 1989). Portlandia arctica, Thyasira gouldi and Yoldiella spp. are present within the Onuphid and Maldanid (= Astarte crenata-Bathyarca glacialis) associations that occur on mixed substrates of gravel, sand and mud at depths of 125 to $750 \mathrm{~m}$ in Baffin Island fiords (Syvitski et al., 1989; Aitken and Fournier, 1993).

The Thyasira association observed in Jørgen Brønlund Fjord is impoverished in terms of both the diversity and abundance of molluscs - characteristics it shares with the prodeltaic Portlandia-Thyasira association observed in Expedition Fiord (Table 4). The distribution of the Thyasira association on clay substrates at depths greater than $20 \mathrm{~m}$ seaward of the fiord-head prodeltaic environment, however, is similar to that of the deep-water Portlandia-Thyasira association observed in Expedition Fiord. As in Expedition Fiord, deep-water environments in Jørgen Brønlund Fjord are characterized by the depostion of clay from suspension in brackish surface waters and salinities greater than 30\%o (Just, 1970).

The species composition of the Portlandia-Hiatella association inhabiting Jørgen Brønlund Fjord (Table 4) resembles 
TABLE 4. Comparison of the species composition of marine mollusc associations occurring in high-latitude fiords.

Portlandia-Thyasira association recorded in Expedition Fiord and Jørgen Brønlund Fjord:

\begin{tabular}{|c|c|c|c|c|}
\hline \multirow[b]{2}{*}{ Depth (m): } & \multicolumn{2}{|c|}{$\begin{array}{l}\text { Expedition } \\
\text { Fiord, } \\
\text { Axel Heiberg } \\
\text { Island }\end{array}$} & \multirow{2}{*}{$\begin{array}{l}\text { Jørgen } \\
\text { Brønlund } \\
\text { Fjord, } \\
\text { Greenland } \\
22-48^{3}\end{array}$} & \multirow{2}{*}{$\begin{array}{l}\text { Itirbilung and } \\
\text { Coronation } \\
\text { Fiords, } \\
\text { Baffin Island } \\
55-148^{4}\end{array}$} \\
\hline & $15-57^{1}$ & $32-82^{2}$ & & \\
\hline \multicolumn{5}{|l|}{ Bivalvia } \\
\hline Delectopecten greenlandicus & & $\mathrm{X}$ & & \\
\hline Portlandia arctica & $\mathrm{X}$ & $\mathrm{X}$ & & $\mathrm{X}$ \\
\hline Thyasira dunbari & $\mathrm{X}$ & & $X$ & \\
\hline Thyasira gouldi & $\mathrm{X}$ & $X$ & & \\
\hline Thyasira pygmaea & & & $\mathrm{X}$ & \\
\hline Yoldiella intermedia & & $X$ & $\mathrm{X}$ & \\
\hline Yoldiella lenticula & & $X$ & & \\
\hline \multicolumn{5}{|l|}{ Gastropoda } \\
\hline Buccinum sp. & & & & $\mathrm{X}$ \\
\hline Naticidae & & $\mathrm{X}$ & & \\
\hline \multicolumn{5}{|l|}{ Scaphopoda } \\
\hline Siphonodentalium lobatum & & $X$ & & \\
\hline
\end{tabular}

Astarte association recorded in Expedition Fiord:

\begin{tabular}{|c|c|c|c|c|c|}
\hline & & \multicolumn{2}{|c|}{$\begin{array}{l}\text { Expedition } \\
\text { Fiord, } \\
\text { Axel Heiberg } \\
\text { Island }\end{array}$} & \multirow[t]{3}{*}{$\begin{array}{c}\text { Franz Joseph } \\
\text { Fjord, } \\
\text { Greenland }\end{array}$} & \multirow[t]{2}{*}{$\begin{array}{l}\text { Scoresby } \\
\text { Sund, } \\
\text { Greenland }\end{array}$} \\
\hline & & $\begin{array}{l}\text { Middle } \\
\text { Fiord }\end{array}$ & $\begin{array}{l}\text { Outer } \\
\text { Fiord }\end{array}$ & & \\
\hline Species & Depth (m): & $3-20$ & $4-32$ & & $5-50^{5}$ \\
\hline
\end{tabular}

\section{Bivalvia}

Astarte borealis

Astarte elliptica

Astarte montagui

Astarte warhami

Bathyarca glacialis

Clinocardium ciliatum

Cuspidaria arctica

Dacridium vitreum

Delectopecten greenlandicus

Hiatella arctica

Lyonsia arenosa

Macoma calcarea

Macoma loveni

Macoma moesta

Musculus discors

Musculus niger

Mya truncata

Nucula tenuis

Nuculana pernula

Pandora glacialis

Portlandia arctica

Thracia devexa

Thyasira gouldi

Serripes groenlandicus

Yoldiella frigida

Yoldiella intermedia

Yoldiella lenticula

Gastropoda

Alvania janmayeni

Buccinum hydrophanum

Colus sp.

Cylichna alba

Cylichna occulta

Lepeta caeca

Lunatia pallida

Margarites groenlandicus

Astarte association recorded in Expedition Fiord continued:

\begin{tabular}{|c|c|c|c|c|c|}
\hline & & $\begin{array}{r}\text { Expe } \\
\text { Fi } \\
\text { Axel I } \\
\text { Isl }\end{array}$ & $\begin{array}{l}\text { tion } \\
\text { iberg } \\
\text { d }\end{array}$ & $\begin{array}{c}\text { Franz Joseph } \\
\text { Fjord, } \\
\text { Greenland }\end{array}$ & $\begin{array}{l}\text { Scoresby } \\
\text { Sund, } \\
\text { Greenland }\end{array}$ \\
\hline Species & $\begin{array}{l}\text { Fiord: } \\
\text { Depth }(\mathrm{m}) \text { : }\end{array}$ & $\begin{array}{l}\text { Middle } \\
3-20\end{array}$ & $\begin{array}{l}\text { Outer } \\
4-32\end{array}$ & $3-45^{5}$ & $5-50^{5}$ \\
\hline
\end{tabular}

Gastropoda continued:

Oenopota bicarinata

Oenopota novajasemliensis

Oenopota pyramidalis

Oenopota tenuiscostata

Trichotropis borealis

$\mathrm{X}$

$\begin{array}{lll} & \mathrm{X} & \\ \mathrm{X} & \mathrm{X} & \mathrm{X} \\ & \mathrm{X} & \mathrm{X} \\ & \mathrm{X} & \end{array}$

Portlandia-Hiatella association recorded in Jørgen Brønlund Fjord:

\begin{tabular}{|c|c|c|c|c|c|}
\hline & \multirow[b]{2}{*}{ Fiord: } & \multicolumn{2}{|c|}{$\begin{array}{c}\text { Jørgen } \\
\text { Brønlund } \\
\text { Fjord, } \\
\text { Greenland }\end{array}$} & \multirow[t]{2}{*}{$\begin{array}{l}\text { McBeth } \\
\text { Fiord, } \\
\text { Baffin } \\
\text { Island }\end{array}$} & \multirow[t]{2}{*}{$\begin{array}{l}\text { Scoresby } \\
\text { Sund, } \\
\text { Greenland }\end{array}$} \\
\hline & & $\begin{array}{l}\text { Inner/ } \\
\text { Middle }\end{array}$ & $\begin{array}{c}\text { Middle/ } \\
\text { Outer }\end{array}$ & & \\
\hline pecies & Depth (m): & $5-19$ & $5-19$ & $5-40^{6}$ & $10-60$ \\
\hline
\end{tabular}

\section{Bivalvia}

Astarte borealis

Astarte warhami

Axinopsida orbiculata

Clinocardium ciliatum

Delectopecten greenlandicus

Hiatella arctica

Macoma calcarea

Musculus discors

Musculus niger

Mya truncata

Nucula belloti

Periploma abyssorum

Portlandia arctica

Thracia sp.

Thracia devexa

Thracia truncata

Thyasira gouldi

Gastropoda

Cylichna alba

Cylichna occulta

Cylichna sp.

Diaphana minuta

Entocolax ludwigi

Oenopota bicarinata

Philine sp.

Retusa obtusa

Trichotropis borealis

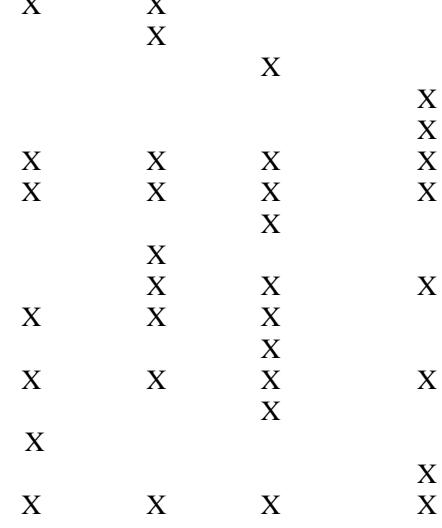

${ }^{1}$ Portlandia-Thyasira association inhabiting the prodeltaic environment as described in this study

2 Portlandia-Thyasira association inhabiting the middle and outer fiord as described in this study

${ }^{3}$ Thyasira association as described in this study

4 Pioneering Portlandia association as described by Syvitski et al. (1989)

5 Macoma calcarea association as described by Thorson (1933, 1934)

${ }^{6}$ Mature Portlandia association as described by Syvitski et al. (1989), Aitken and Fournier (1993) 
that of Portlandia associations recorded in McBeth Fiord, Baffin Island (Syvitski et al., 1989; Aitken and Fournier, 1993) and in Scoresby Sund, Greenland (Thorson, 1934). $P$. arctica is generally considered to occur in greatest abundance on soft clay substrates close to river mouths and active glacier margins, environments characterized by rapid sedimentation and markedly reduced salinities (Ockelmann, 1958; Lubinsky, 1980). At McBeth Fiord and Scoresby Sund, $P$. arctica is abundant at depths of 5-60 min fiord-head prodeltaic environments, and is found in association with Hiatella arctica, Astarte borealis, Macoma calcarea, Mya truncata, Thyasira gouldi and Delectopecten greenlandicus. In contrast to the situation in McBeth Fiord and Scoresby Sund, the Portlandia-Hiatella association occurs throughout the length of Jørgen Brønlund Fjord (Schiøtte, 1989). In McBeth Fiord, sediment-laden meltwater derived from hinterland glaciers passes over an extensive outwash plain. Sediment deposition within braided stream channels traversing the outwash plain surface reduces the input of clastic sediment to the fiord-head environment. In this situation organic carbon, derived from phytoplankton and benthic macroalgae, represents a greater fraction of the suspended sediment delivered to the benthos (Syvitski et al., 1989, 1990). This, in turn, may facilitate the shift from a macrofauna dominated by molluscs that are tolerant of food-limited environments, such as Portlandia arctica and Thyasira spp. (Yonge and Thompson, 1976), to a more diverse fauna of suspension-feeding molluscs characterized by the presence of Astarte, Hiatella and Mya.

The Astarte association inhabiting shallow waters in Expedition Fiord corresponds to the arctic Macoma association described by Thorson $(1933,1934)$ from Greenland fiords (Table 4) and the Astarte association on the inner continental shelf of eastern Baffin Island described by Thomson et al. (1986). The Macoma-Astarte association is characterized by the presence and abundance of Astarte borealis, Macoma calcarea, Mya truncata, and Hiatella arctica. This macrobenthos association inhabits mixed substrates of sand and mud at depths of 5-50 m throughout its range of distribution. The absence of the Astarte association in the inner basin of Expedition Fiord most probably relates to the intolerance of suspension-feeding molluscs such as Astarte, Hiatella, Mya and Trichotropis for the elevated suspended sediment concentrations encountered in this environment.

\section{CONCLUSIONS}

The molluscs recovered from Expedition Fiord, Axel Heiberg Island, and Jørgen Brønlund Fjord, Greenland are distributed widely within high-latitude estuaries and across the continental shelves bordering the Arctic Ocean. On the basis of their presence or absence in dredge samples, the 26 species of marine molluscs recovered from Expedition Fiord (17 bivalves, 8 gastropods, and 1 scaphopod) cluster into two discrete mollusc associations. In shallow water (3-32 m), an Astarte association is characterized by the presence and abundance of Astarte borealis and Astarte warhami. In deep water (> $32 \mathrm{~m}$ ), a Portlandia-Thyasira association is characterized by the presence and abundance of Portlandia arctica and Thyasira gouldi. In contrast to Expedition Fiord, the shallow-water (5-19 m) Portlandia-Hiatella association recorded in Jørgen Brønlund Fjord is characterized by the presence and abundance of Portlandia arctica and Hiatella arctica. The deep-water $(22-48 \mathrm{~m})$ Thyasira association recorded in Jørgen Brønlund Fjord is characterized by the presence and abundance of Thyasira dunbari and Yoldiella intermedia.

The prodeltaic environment of Expedition River is inhabited by an impoverished Portlandia-Thyasira association consisting only of Portlandia arctica and Thyasira spp. These molluscs apparently tolerate the high sedimentation rates, low salinities $\left(<30 \%\right.$ ) and low temperatures $\left(<0^{\circ} \mathrm{C}\right)$ that characterize the prodeltaic environment. The PortlandiaThyasira association observed in middle and outer Expedition Fiord inhabits an environment characterized by low sedimentation rates and salinities greater than $30 \%$. This mollusc association is differentiated from the fiord-head Portlandia-Thyasira association by the presence of the bivalves Delectopecten greenlandicus and Yoldiella spp. and the scaphopod Siphonodentalium lobatum.

The shallow-water Astarte association is not present at the fiord head. High suspended-sediment concentrations in inner Expedition Fiord preclude the presence of suspension-feeding molluscs such as Astarte, Hiatella, and Macoma: hence the absence of the Astarte association in this environment. The presence of sea ice also restricts the distribution of this mollusc association in Expedition Fiord. The absence of benthic macrofauna at depths of less than $3 \mathrm{~m}$ may be attributed to mortality due to direct freezing of organisms during icefoot development, abrasion by drift ice during breakup in early summer, and physiological stress associated with lower salinities created by melting sea ice and icebergs in summer. The processes contributing to the development and persistence of a barren zone to a depth of $3 \mathrm{~m}$ in Expedition Fiord remain to be investigated.

\section{ACKNOWLEDGEMENTS}

The research project was supported by the Natural Sciences and Engineering Research Council of Canada (NSERC) through research grants to R. Gilbert and A.E. Aitken and an NSERC postdoctoral fellowship granted to A.E. Aitken. The Polar Continental Shelf Project of Natural Resources Canada provided logistical support in the field. The loan of two Kolquitz dredges from the Canadian Museum of Nature, Ottawa is gratefully acknowledged. Gwyneth Hall and Paul Cascagnette assisted in the field and with data analysis, respectively. Dr. Peta Mudie, Natural Resources Canada, provided access to mollusc collections from the continental shelf of Axel Heiberg Island. Illustrations were prepared by Keith Bigelow and Derek Thompson, Department of Geography, University of Saskatchewan. The authors acknowlege the constructive comments provided by A.G. Lewis, Nora Foster, Howard Feder, and an anonymous reviewer. 
APPENDIX 1. Living molluscs recovered in dredge samples from Expedition Fiord, Axel Heiberg Island. Stations from Sites A, B and F.

\begin{tabular}{|c|c|c|c|c|c|c|c|c|c|c|c|c|c|}
\hline & \multicolumn{3}{|c|}{ Inner Fiord } & \multicolumn{10}{|c|}{ Middle Fiord } \\
\hline $\begin{array}{r}\text { Station } \\
\text { Depth (m) }\end{array}$ & $\begin{array}{l}\text { B2 } \\
57\end{array}$ & $\begin{array}{c}\text { B3 } \\
15-20\end{array}$ & $\begin{array}{c}\text { B5 } \\
79-81\end{array}$ & $\begin{array}{c}\text { B6 } \\
34-39\end{array}$ & $\begin{array}{c}\mathrm{A} 1 \\
22-40\end{array}$ & $\begin{array}{c}\mathrm{A} 2 \\
35-44\end{array}$ & $\begin{array}{c}\mathrm{A} 3 \\
55-67\end{array}$ & $\begin{array}{c}\mathrm{A} 4 \\
79-81\end{array}$ & $\begin{array}{c}\mathrm{A} 6 \\
10-15\end{array}$ & $\begin{array}{c}\mathrm{F} 1 \\
3.4-8.8\end{array}$ & $\begin{array}{c}\mathrm{F} 2 \\
16-24\end{array}$ & $\begin{array}{c}\text { F3 } \\
32-45\end{array}$ & $\begin{array}{c}\mathrm{F} 4 \\
55-65\end{array}$ \\
\hline \multicolumn{14}{|l|}{ Bivalvia } \\
\hline Astarte borealis & & & & & & & & & $\mathrm{X}$ & $\mathrm{X}$ & $\mathrm{X}$ & $\mathrm{X}$ & \\
\hline Astarte warhami & & & & & & & & & $\mathrm{X}$ & $\mathrm{X}$ & & & \\
\hline Delectopecten greenlandicus & & & & & & & $\mathrm{X}$ & & & & & & \\
\hline Hiatella arctica & & & & & & & & & & $\mathrm{X}$ & & & \\
\hline Macoma loveni & & & & & & & & & & $\mathrm{X}$ & & & \\
\hline Mya truncata & & & & & & & & & & $\mathrm{X}$ & & & \\
\hline Portlandia arctica & $\mathrm{X}$ & $\mathrm{X}$ & & $\mathrm{X}$ & & & $\mathrm{X}$ & $\mathrm{X}$ & & & & $\mathrm{X}$ & $\mathrm{X}$ \\
\hline Thyasira dunbari & $\mathrm{X}$ & & & & & & & & & & & & \\
\hline Thyasira gouldi & & & & $\mathrm{X}$ & & & & $\mathrm{X}$ & & & & $\mathrm{X}$ & $\mathrm{X}$ \\
\hline Yoldiella fraterna & & & & & & & & & & & & $\mathrm{X}$ & \\
\hline Yoldiella lenticula & & & & & & & $\mathrm{X}$ & $\mathrm{X}$ & & & $\mathrm{X}$ & & $\mathrm{X}$ \\
\hline \multicolumn{14}{|l|}{ Gastropoda } \\
\hline Naticidae (egg cases) & & & & $\mathrm{X}$ & & & & $\mathrm{X}$ & & & & & \\
\hline Cylichna occulta & & & & & & & & & $\mathrm{X}$ & & & & \\
\hline Oenopota sp. & & & & & & & & & & & & & $\mathrm{X}$ \\
\hline Trichotropis borealis & & & & & & & & & $\mathrm{X}$ & & & & \\
\hline
\end{tabular}

APPENDIX 2. Living molluscs recovered in dredge samples from Expedition Fiord, Axel Heiberg Island. Stations from Sites C, D and E.

\begin{tabular}{|c|c|c|c|c|c|c|c|c|c|c|c|c|c|c|}
\hline \multirow[b]{2}{*}{$\begin{array}{r}\text { Station } \\
\text { Depth }(\mathrm{m})\end{array}$} & \multicolumn{5}{|c|}{ Middle Fiord } & \multicolumn{9}{|c|}{ Outer Fiord } \\
\hline & $\begin{array}{c}\text { D1 } \\
4-4.6\end{array}$ & $\begin{array}{c}\mathrm{D} 2 \\
9-13.8\end{array}$ & $\begin{array}{c}\text { D3 } \\
18-20\end{array}$ & $\begin{array}{c}\text { D4 } \\
34-40\end{array}$ & $\begin{array}{c}\text { D5 } \\
57-66\end{array}$ & $\begin{array}{c}\text { E1 } \\
4-6\end{array}$ & $\begin{array}{c}\text { E2 } \\
8-10\end{array}$ & $\begin{array}{c}\text { E4 } \\
32-44\end{array}$ & $\begin{array}{c}\text { E5 } \\
55-65\end{array}$ & $\begin{array}{c}\mathrm{C} 1 \\
5\end{array}$ & $\begin{array}{c}\mathrm{C} 2 \\
14-16.2\end{array}$ & $\begin{array}{c}\mathrm{C} 3 \\
30-32\end{array}$ & $\begin{array}{c}\mathrm{C} 4 \\
48-53\end{array}$ & $\begin{array}{c}\text { C5 } \\
77-82\end{array}$ \\
\hline \multicolumn{15}{|l|}{ Bivalvia } \\
\hline Astarte borealis & $\mathrm{X}$ & $\mathrm{X}$ & $\mathrm{X}$ & & & $\mathrm{X}$ & $\mathrm{X}$ & $\mathrm{X}$ & & & $\mathrm{X}$ & & & \\
\hline Astarte warhami & & $\mathrm{X}$ & $\mathrm{X}$ & $\mathrm{X}$ & $\mathrm{X}$ & $X$ & $\mathrm{X}$ & & $\mathrm{X}$ & $\mathrm{X}$ & $\mathrm{X}$ & $\mathrm{X}$ & $X$ & \\
\hline Clinocardium ciliatum & & $X$ & $\mathrm{X}$ & & & & & & & & & & & \\
\hline Cuspidaria arctica & & $\mathrm{X}$ & & & & & & & & & & $\mathrm{X}$ & & \\
\hline Delectopecten greenlandicus & & & & $\mathrm{X}$ & & & & & & & $\mathrm{X}$ & & & \\
\hline Hiatella arctica & $\mathrm{X}$ & & & $\mathrm{X}$ & & $\mathrm{X}$ & & & & $\mathrm{X}$ & & $\mathrm{X}$ & & \\
\hline Macoma calcarea & $\mathrm{X}$ & $\mathrm{X}$ & & & & & & & & & $\mathrm{X}$ & & & \\
\hline Macoma loveni & & & $\mathrm{X}$ & & & $\mathrm{X}$ & & & & $\mathrm{X}$ & & $\mathrm{X}$ & & \\
\hline Mya truncata & & & & & & $\mathrm{X}$ & & & & & & $\mathrm{X}$ & & \\
\hline Nuculana pernula costigera & & $\mathrm{X}$ & & $\mathrm{X}$ & & & & & & & & & & \\
\hline Portlandia arctica & $\mathrm{X}$ & & & & & $\mathrm{X}$ & $\mathrm{X}$ & & $\mathrm{X}$ & & & & & \\
\hline Thracia devexa & & $\mathrm{X}$ & & & & $\mathrm{X}$ & & & & & & & & \\
\hline Thyasira gouldi & & & & & & & & $\mathrm{X}$ & $\mathrm{X}$ & $\mathrm{X}$ & & & & $\mathrm{X}$ \\
\hline Thyasira dunbari & & & & & & & $\mathrm{X}$ & & & & & & & \\
\hline Yoldiella intermedia & & & & $\mathrm{X}$ & $\mathrm{X}$ & & & & & & & & $\mathrm{X}$ & \\
\hline Yoldiella lenticula & & $\mathrm{X}$ & & $\mathrm{X}$ & $\mathrm{X}$ & & & & & & & & & $\mathrm{X}$ \\
\hline \multicolumn{15}{|l|}{ Scaphopoda } \\
\hline Siphonodentalium lobatum & & & & & & & & & & & & & $\mathrm{X}$ & $\mathrm{X}$ \\
\hline \multicolumn{15}{|l|}{ Gastropoda } \\
\hline Cylichna alba & & & $\mathrm{X}$ & & & & & & & & & & & \\
\hline Cylichna occulta & $\mathrm{X}$ & & & & & $X$ & $\mathrm{X}$ & & & $\mathrm{X}$ & $\mathrm{X}$ & $\mathrm{X}$ & & \\
\hline Lepeta caeca & & & & $\mathrm{X}$ & & & & & & & & & & \\
\hline Oenopota cinerea & & & & & & $\mathrm{X}$ & & & & & & & & \\
\hline Oenopota decussata & & & & & & & & & & & & $\mathrm{X}$ & & \\
\hline Oenopota novajasemliensis & & $\mathrm{X}$ & $\mathrm{X}$ & & & & & $\mathrm{X}$ & $\mathrm{X}$ & & $\mathrm{X}$ & & & \\
\hline Oenopota reticulata & & & & & & & $\mathrm{X}$ & & & & & & & \\
\hline Trichotropis borealis & $\mathrm{X}$ & & & & & $\mathrm{X}$ & & & & $\mathrm{X}$ & & $\mathrm{X}$ & & \\
\hline
\end{tabular}


APPENDIX 3. Living molluscs recovered in dredge samples from Jørgen Brønlund Fjord, Greenland.

\begin{tabular}{|c|c|c|c|c|c|c|c|c|c|c|c|c|c|c|c|c|c|c|c|c|c|c|}
\hline \multirow{3}{*}{$\begin{array}{r}\text { Station } \\
\text { Depth (m) }\end{array}$} & \multicolumn{10}{|c|}{ Inner Fiord } & \multicolumn{8}{|c|}{ Middle Fiord } & \multicolumn{4}{|c|}{ Outer Fiord } \\
\hline & H1 & H1 & $\mathrm{H} 2$ & $\mathrm{H} 2$ & $\mathrm{H} 3$ & $\mathrm{H} 8$ & H9 & H9 & H11 & H11 & $\mathrm{H} 4$ & $\mathrm{H} 4$ & H12 & H13 & H13 & H14 & H14 & H15 & H5 & H5 & $\mathrm{H} 7$ & $\mathrm{H} 7$ \\
\hline & 10 & 10 & 48 & 48 & 28 & 22 & 16 & 16 & 5 & 5 & 12 & 12 & 12 & 5 & 5 & 19 & 19 & 19 & 25 & 25 & 7 & 7 \\
\hline \multicolumn{23}{|l|}{ Bivalvia } \\
\hline Astarte borealis & $\mathrm{X}$ & $\mathrm{X}$ & & & & & $\mathrm{X}$ & $\mathrm{X}$ & & & & & $\mathrm{X}$ & $\mathrm{X}$ & $\mathrm{X}$ & & & & & & $\mathrm{X}$ & $\mathrm{X}$ \\
\hline Astarte montagui & & & & & & & & & & & & $\mathrm{X}$ & & & & & & & & & & \\
\hline Astarte warhami & & & & $\mathrm{X}$ & & & $\mathrm{X}$ & & & & & & $\mathrm{X}$ & $\mathrm{X}$ & $\mathrm{X}$ & & $\mathrm{X}$ & $\mathrm{X}$ & & & & $\mathrm{X}$ \\
\hline Axinopsida orbiculata & & & & & & & & & & & & & $\mathrm{X}$ & & & & & & & & & \\
\hline Bathyarca glacialis & & & $\mathrm{X}$ & & & & & & & & & & & & & & & & & & & \\
\hline Hiatella arctica & & & & & & & $\mathrm{X}$ & $\mathrm{X}$ & $\mathrm{X}$ & $\mathrm{X}$ & $\mathrm{X}$ & $\mathrm{X}$ & $X$ & $\mathrm{X}$ & $\mathrm{X}$ & & & & & & $\mathrm{X}$ & $\mathrm{X}$ \\
\hline Macoma calcarea & $\mathrm{X}$ & & & & & & $\mathrm{X}$ & $\mathrm{X}$ & $\mathrm{X}$ & $\mathrm{X}$ & & $\mathrm{X}$ & & $\mathrm{X}$ & & & & & & & $\mathrm{X}$ & $\mathrm{X}$ \\
\hline Macoma loveni & & & & & & & & & & & & & $X$ & & $X$ & & $\mathrm{X}$ & $X$ & & & & \\
\hline Musculus niger & & & & & & & & & & & & & $\mathrm{X}$ & & & & $\mathrm{X}$ & $\mathrm{X}$ & & & & \\
\hline Mya truncata & & & & & & & $\mathrm{X}$ & & & & & & & & & & & $\mathrm{X}$ & & & $\mathrm{X}$ & \\
\hline Nucula belloti & $\mathrm{X}$ & $\mathrm{X}$ & & & & & & & & $\mathrm{X}$ & $\mathrm{X}$ & $\mathrm{X}$ & $\mathrm{X}$ & $\mathrm{X}$ & $\mathrm{X}$ & & $\mathrm{X}$ & & & & $\mathrm{X}$ & $\mathrm{X}$ \\
\hline Nucula tenuis & & & & & & & & & & & & & & & & & & $\mathrm{X}$ & & & & \\
\hline Portlandia arctica & & & & & & & $\mathrm{X}$ & & $\mathrm{X}$ & $\mathrm{X}$ & & $\mathrm{X}$ & $\mathrm{X}$ & $\mathrm{X}$ & $\mathrm{X}$ & & & & & & $\mathrm{X}$ & $\mathrm{X}$ \\
\hline Thracia devexa & & & & & & & & $\mathrm{X}$ & & & & & & & & & $\mathrm{X}$ & & & & & \\
\hline Thyasira dunbari & & & $\mathrm{X}$ & $\mathrm{X}$ & $\mathrm{X}$ & $X$ & & & & & & & & & & & & $\mathrm{X}$ & $\mathrm{X}$ & $X$ & & \\
\hline Thyasira gouldi & $\mathrm{X}$ & $\mathrm{X}$ & & & & & $\mathrm{X}$ & $\mathrm{X}$ & & & & $\mathrm{X}$ & & $\mathrm{X}$ & & & & & & & $X$ & $\mathrm{X}$ \\
\hline Thyasira pygmaea & & & $\mathrm{X}$ & $\mathrm{X}$ & & & & & & & & & & & & & & & & & & \\
\hline Yoldiella intermedia & & & $X$ & $X$ & & & & & & & & & & & & & & & & & & \\
\hline \multicolumn{23}{|l|}{ Gastropoda } \\
\hline Chaetoderma productum & & & & & & & $\mathrm{X}$ & & & & & & & & & & & & & & & \\
\hline Cylichna alba & $\mathrm{X}$ & $\mathrm{X}$ & & & & & & $\mathrm{X}$ & & & $\mathrm{X}$ & $\mathrm{X}$ & & & & $\mathrm{X}$ & & & & & & $\mathrm{X}$ \\
\hline Cylichna occulta & & & & & & & $\mathrm{X}$ & & & & & & & $\mathrm{X}$ & & & & & & & & \\
\hline Diaphana minuta & & & & & & & & $\mathrm{X}$ & & & & & $\mathrm{X}$ & & & & & & & & & \\
\hline Entocolax ludwigi & & & & & & & & & & & $\mathrm{X}$ & & $\mathrm{X}$ & & & & & & & & & \\
\hline Oenopota bicarinata & & & & & & & & & & & $\mathrm{X}$ & & & $\mathrm{X}$ & & & & & & & & \\
\hline Oenopota novajasemliensis & & & & & & & & & & & & & & & $\mathrm{X}$ & & & & & & & \\
\hline Retusa obtusa & & & & & & & & & & & $\mathrm{X}$ & $\mathrm{X}$ & $\mathrm{X}$ & & & & & & & & & \\
\hline Trichotropis borealis & $\mathrm{X}$ & & & & & & & & & & & & & & & & & & & & & \\
\hline
\end{tabular}

APPENDIX 4. Marine molluscs dredged on the continental shelf of Axel Heiberg Island during cruises 85200 and 86200 of the Atlantic Geoscience Centre, Natural Resources Canada, Bedford Institute of Oceanography; (B) bivalve, (G) gastropod, (S) scaphopod.

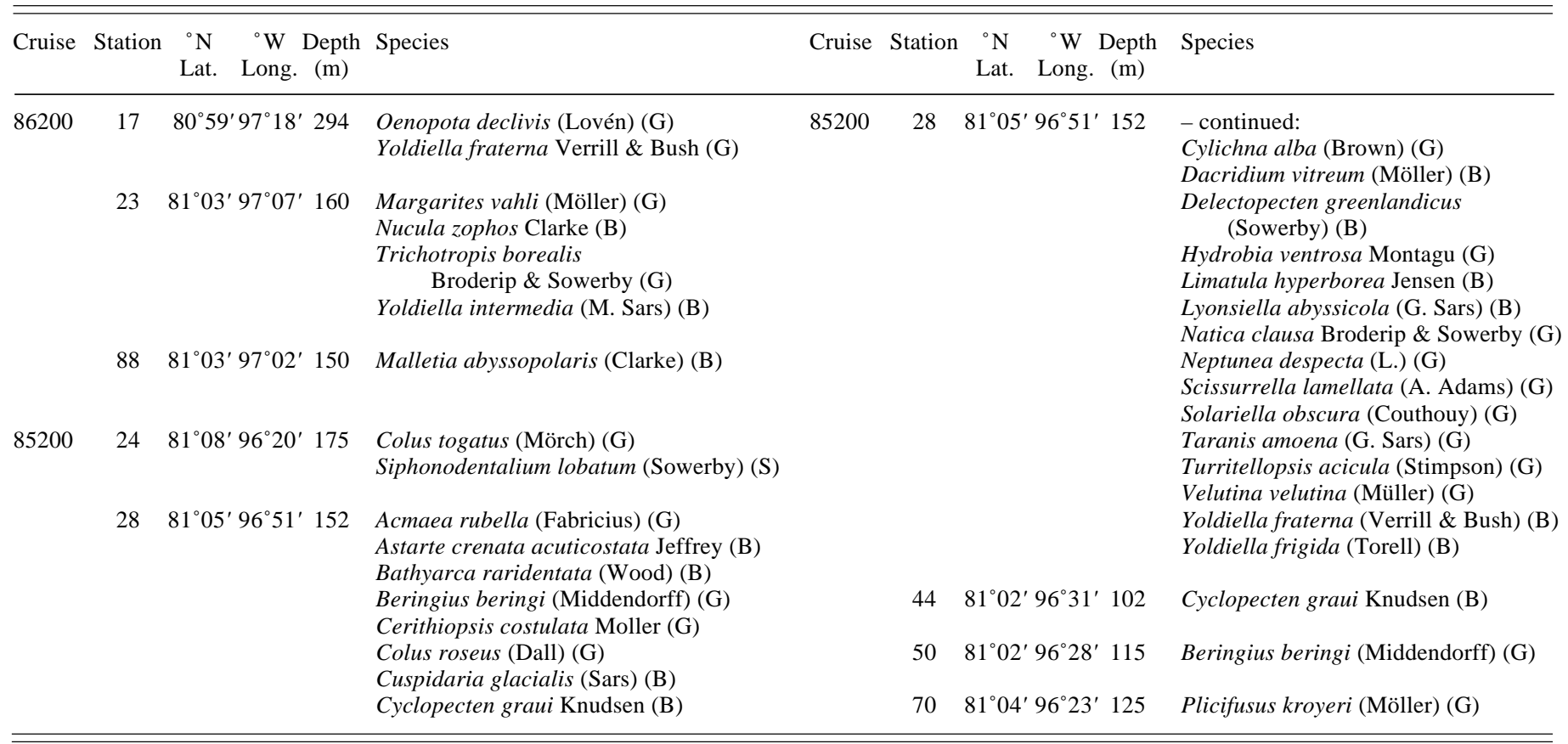




\section{REFERENCES}

AITKEN, A.E., and FOURNIER, J. 1993. Macrobenthos communities of Cambridge, McBeth and Itirbilung Fiords, Baffin Island, Northwest Territories, Canada. Arctic 46:60-71.

AITKEN, A.E., RISK, M.J., and HOWARD, J.D. 1988. Animalsediment relationships on a subarctic intertidal flat, Pangnirtung Fiord, Baffin Island, Canada. Journal of Sedimentary Petrology 58:969-978.

ASPREY, K.W., BISHOP, P., BLAKENEY, C., LeBLANC, W., SYVITSKI, J.P.M., and WINTERS, G. 1983. SAFE 1982 suspended particulate matter data. In: Syvitski, J.P.M., and Blakeney, C., compilers. Sedimentology of Arctic Fjords Experiment: HU82-031 Data Report, Volume 1. Canadian Data Report of Hydrography and Ocean Sciences 12. 5-1 to 5-30.

BAILEY, W.B. 1957. Oceanographic features of the Canadian Archipelago. Journal of the Fisheries Research Board of Canada 14:731-769.

BASS, D.W., and LEVER, J.H. 1989. Dynamic simulations of iceberg-seabed interactions. Cold Regions Science and Technology 17:137-151.

BERGERON, P., and BOURGET, E. 1984. Effet du froid et des glaces sur les peuplements intertidaux des régions nordiques, particulièrement dans l'estuaire Saint-Laurent. Oceanis 10(3):279-304.

CAREY, A.G., Jr. 1991. Ecology of North American Arctic continental shelf benthos: A review. Continental Shelf Research 11:865-883.

CAREY, A.G., Jr., and RUFF, R.E. 1977. Ecological studies of the benthos in the western Beaufort Sea with special reference to the bivalve molluscs. In: Dunbar, M.J., ed. Polar oceans. Washington, D.C.: Arctic Institute of North America. 505-530.

COACHMAN, L.K., and AAGAARD, K. 1974. Physical oceanography of the Arctic and Subarctic seas. In: Herman, Y., ed. Marine geology and oceanography of the Arctic seas. New York: Springer-Verlag. 1-72.

CURTIS, M.A. 1972. Depth distribution of benthic polychaetes in two fiords on Ellesmere Island, N.W.T. Journal of the Fisheries Research Board of Canada 29:1319-1327.

DALE, J.E. 1985. Recent intertidal molluscs from the east-central coast of Ellesmere Island, Northwest Territories. Geological Survey of Canada Paper 85-1B:319-324.

DALE, J.E., AITKEN, A.E., GILBERT, R., and RISK, M.J. 1989. Macrofauna of Canadian arctic fjords. Marine Geology 85:331 385.

DUNBAR, M.J. 1951. Eastern arctic waters. Bulletin of the Fisheries Research Board of Canada No. 88.

ELLIS, D.V., and WILCE, R.T. 1961. Arctic and subarctic examples of intertidal zonation. Arctic 14:224-235.

GEORGE, R.Y. 1977. Dissimilar amd similar trends in Antarctic and arctic marine benthos. In: M.J. Dunbar, ed. Polar oceans. Washington, D.C.: Arctic Institute of North America. 391-408.

GILBERT, R. 1990. Sedimentation in Expedition Fiord, Axel Heiberg Island, Northwest Territories. Géographie physique et Quaternaire 40:71-76.
GILBERT, R., AITKEN, A.E., and LEMMEN, D.S. 1993. The glacimarine sedimentary environment of Expedition Fiord, Canadian High Arctic. Marine Geology 110:257-273.

GORDON, D.C., Jr., and DESPLANQUE, C. 1983. Dynamics and environmental effects of ice in the Cumberland Basin of the Bay of Fundy. Canadian Journal of Fisheries and Aquatic Sciences 40:1331-1342.

HUNTER, J.G., and LEACH, S.T. 1983. Hydrographic data collected during fisheries activities of the Arctic Biological Station, 1960 to 1979. Canadian Data Report of Fisheries and Aquatic Sciences No. 414. 87 p.

JOHNSON, G.L., GRANTZ, A., and WEBER, J.R. 1990. Bathymetry and physiography. In: Grantz, A., Johnson, G.L., and Sweeney, J.F., eds. The Arctic Ocean region. Geology of North America, Volume L. Boulder, Colorado: Geological Society of North America. 63-77.

JONES, B. 1988. Biostatistics in paleontology. Geoscience Canada $15: 3-22$.

JUST, J. 1970. Marine biological investigations of Jørgen Brønlund Fjord, North Greenland. Meddelelser om Grønland 184(5). 42 p.

LEMCHE, H. 1941. The zoology of East Greenland. Gastropoda Opisthobranchiata. Meddelelser om Grønland 121(7). 50 p.

LEMMEN, D.S., AITKEN, A.E., and GILBERT, R. 1994. Early Holocene deglaciation of Expedition and Strand Fiords, Canadian High Arctic. Canadian Journal of Earth Sciences 31:943-958.

LEWIS, E.L. 1989. The Arctic Ocean: Water masses and energy exchanges. In: Rey, L., ed. The Arctic Ocean: The hydrographic environment and the fate of pollutants. London: MacMillan Press Ltd. 43-68.

LUBINSKY, I. 1980. Marine bivalve molluscs of the Canadian Central and Eastern Arctic: Faunal composition and zoogeography. Canadian Bulletin of Fisheries and Aquatic Sciences, Bulletin 207. 111 p.

MAAG, H. 1969. Ice-dammed lakes and marginal glacial drainage on Axel Heiberg Island. Axel Heiberg Island Research Reports, McGill University, Montréal, Québec. 147 p.

MacGINITIE, G.E. 1955. Distribution and ecology of the marine invertebrates of Point Barrow, Alaska, Smithsonian Miscellaneous Collection 128:1-201.

MACPHERSON, E. 1971. The marine molluscs of arctic Canada. National Museums of Canada, Publications in Biological Oceanography 3. $149 \mathrm{p}$.

MADSEN, H. 1936. Investigations on the shore fauna of East Greenland with a survey of the shores of other arctic regions. Meddelelser om Grønland 100(8). 79 p.

- 1940. A study of the littoral fauna of Northwest Greenland. Meddelelser om Grønland 124(3). 24 p.

MEDCOF, J.C., and THOMAS, M.L.H. 1974. Surfacing on ice of frozen-in bottom materials. Journal of the Fisheries Research Board of Canada 31:1195-1200.

MEUNCH, R.D. 1971. The physical oceanography of the northern Baffin Bay region. Baffin Bay-North Water Project, Scientific Report 1. Washington, D.C.: Arctic Institute of North America. OCKELMANN, W.K. 1958. The zoology of East Greenland. Marine Lamellibranchiata. Meddelelser om Grønland 122(4). 256 p. 
PEREIRA, C.P.G., WOODWORTH-LYNAS, C.M.T., and BARRIE, J.V. 1988. Iceberg scour investigations and sedimentology of the southeast Baffin Island continental shelf. Arctic 41:221-230.

PETERSEN, G.H. 1977. Biological effects of sea-ice and icebergs in Greenland. In: Dunbar, M.J., ed. Polar oceans. Washington, D.C.: Arctic Institute of North America. 319-329.

REIMNITZ, E., and KEMPEMA, E.W. 1987. Field observations of slush ice generated during freeze-up in Arctic coastal waters. Marine Geology 77:219-231.

REIMNITZ, E., KEMPEMA, E.W., and BARNES, P.W. 1987. Anchor ice, seabed freezing, and sediment dynamics in shallow Arctic seas. Journal of Geophysical Research 92(C):14 67114678.

REIMNITZ, E., MARINCOVICH, L., Jr., McCORMICK, M., and BRIGGS, W.M. 1992. Suspension freezing of bottom sediment and biota in the Northwest Passage and implications for Arctic Ocean sedimentation. Canadian Journal of Earth Sciences 29:693-703.

REIMNITZ, E., TOIMIL, L., and BARNES, P. 1978. Arctic continental shelf morphology related to sea ice zonation, Beaufort Sea, Alaska. Marine Geology 28:179-210.

RÓZYCKI, O. 1984. Distribution of bivalves in the Van Keulen Fjord (Spitsbergen, Bellsund). Polskie Archiwum Hydrobiologii 31:83-89.

SAS Institute Inc. 1989. SAS/STAT® User's Guide, Version 6, Fourth edition, Volumes 1 and 2. Cary, North Carolina: SAS Institute Inc. $1686 \mathrm{p}$.

SCHIØTTE, T. 1989. Marine mollusca from Jørgen Brønlund Fjord, North Greenland, including the description of Diaphana vedelsbyae n. sp. Meddelelser om Grønland, Bioscience 28. $24 \mathrm{p}$.

SPÄRCK, R. 1933. Contributions to the animal ecology of the Franz Joseph Fjord and adjacent East Greenland waters I-II. Meddelelser om Grønland 100(1). 40 p.

SYVITSKI, J.P.M. 1989. On the deposition of sediment within glacier-influenced fjords: Oceanographic controls. Marine Geology 85:301-330.

SYVITSKI, J.P.M., and HEIN, F.H. 1991. Sedimentology of an arctic basin: Itirbilung Fiord, Baffin Island, Northwest Territories. Geological Survey of Canada Paper 91-11.66 p.
SYVITSKI, J.P.M., FARROW, G.E., ATKINSON, R.G.A., MOORE, P.G., and ANDREWS, J.T. 1989. Baffin Island fjord macrobenthos: Bottom communities and environmental significance. Arctic 42:232-247.

SYVITSKI, J.P.M., LeBLANC, K.W.G., and CRANSTON, R.E. 1990. The flux and preservation of organic carbon in Baffin Island fjords. In: Dowdeswell, J.A., and Scourse, J.D., eds. Glacimarine environments: Processes and sediments. Geological Society of London Special Publication 53. 177-199.

THOMSON, D.H., MARTIN, C.M., and CROSS, W.E. 1986. Identification and characterization of arctic nearshore benthic habitats. Canadian Technical Report of Fisheries and Aquatic Sciences 1434. $70 \mathrm{p}$.

THORSON, G. 1933. Investigations on shallow water animal communities in the Franz Joseph Fjord (East Greenland) and adjacent waters. Meddelelser om Grønland 100(2). 70 p.

1934. Contributions to the animal ecology of the Scoresby Sound Fjord complex (East Greenland). Meddelelser om Grønland 100(3). 67 p.

- 1944. The zoology of East Greenland. Marine Gastropoda Prosobranchiata. Meddelelser om Grønland 121(13). 181 p.

TRITES, R.W., PETRIE, W.M., HAY, A.E., and DeYOUNG, B. 1983. Synoptic oceanography. In: Syvitski, J.P.M., and Blakeney, C., compilers. Sedimentology of Arctic Fjords Experiment: HU 82-031 Data Report, Volume 1. Canadian Data Report of Hydrography and Ocean Sciences $12.2-1$ to 2-129.

VIBE, C. 1939. Preliminary investigations on shallow water animal communities in the Upernavik- and Thule-Districts (Northwest Greenland). Meddelelser om Grønland 124(2). 42 p.

1950. The marine mammals and the marine fauna in the Thule district (Northwest Greenland) with observations on ice conditions in 1939-41. Meddelelser om Grønland 150(6). $115 \mathrm{p}$.

WAGNER, F.J.E. 1964. Faunal report II, Marine geology program, Polar Continental Shelf Project, Isachsen, District of Franklin. Geological Survey of Canada, Bedford Institute of Oceanography Report 64-1. 15 p.

WOODWORTH-LYNAS, C.M.T., JOSENHANS, H.W., BARRIE, J.V., LEWIS, C.F.M., and PARROTT, D.R. 1989. The physical processes of seabed disturbance during iceberg grounding and scouring. Continental Shelf Research 11:939-961.

YONGE, C.Y., and THOMPSON, T.E. 1976. Living marine molluscs. Glasgow: William Collins Sons and Company, Ltd. $288 \mathrm{p}$. 